\title{
STRATEGY AND CONSTRAINTS ON SUPREME COURT OPINION ASSIGNMENT
}

\author{
PAUL J. WAHLBECK ${ }^{\dagger}$
}

\begin{abstract}
The assignment of the Supreme Court's majority opinions is one of the principal prerogatives enjoyed by the Chief Justice. A strategic Chief Justice is able to influence the course of legal policy through agenda setting; that is, the Chief Justice exercises influence over policy by choosing the Justice who will author an opinion, thereby determining which policy alternative will be developed in a majority opinion draft. Through strategic opinion assignment, then, the Chief is able to guide the Court to an outcome that is closest to his preference or that will result in the least policy loss. Despite the importance of this prerogative for agenda setting and the development of the law, the Chief Justice operates within twin constraints: the need for majority support for the proposed opinion and the efficient operation of the Court. In particular, the Chief Justice often assigns opinions to Justices with whom he allies in order to maintain fragile conference majorities. Chief Justice William H. Rehnquist also asserted that his assignments were based on the need to complete work on the cases and to maintain an equitable distribution of cases among the Justices. Using data drawn from the papers of Justice Harry A. Blackmun and other sources, I test these expectations through an examination of opinion assignment during the Rehnquist Court from October Term 1986 through October Term 1993.
\end{abstract}

\section{INTRODUCTION}

Many scholars have characterized the Chief Justice as first among equals. ${ }^{1}$ The absence of additional powers of influence led former Chief Justice William H. Rehnquist, before his ascension to the center seat, to describe the Chief Justice as presiding "over a conference not of eight subordinates, whom he may direct or instruct, but of eight as-

\footnotetext{
${ }^{\dagger}$ Professor of Political Science, The George Washington University. This paper was prepared for presentation at the University of Pennsylvania Law Review's Symposium, The Chief Justice and the Institutional Judiciary, on November 10-11, 2005. I would like to thank John Jacobs of Washington and Lee University and Ryan Schoen of The George Washington University for their assistance in this project.

See, e.g., WALter F. MuRPhy, Elements Of JUdicial STRATEgy 82 (1964) (“[T] he Chief Justice, while usually thought of by his colleagues only as primus inter pares, does have some authority which other members of the Court do not possess."); Sue Davis, Power on the Court: Chief Justice Rehnquist's Opinion Assignments, 74 JUDICATURE 66, 67 (1990) ("The Chief Justice is often described as primus inter pares, 'first among equals."”).
} 
sociates who, like him, have tenure during good behavior, and who are as independent as hogs on ice." ${ }^{2}$ Nevertheless, the Chief Justice enjoys a powerful prerogative in the assignment of majority opinions. The power to assign authorship of the Court's opinion provides the Chief with the capacity to direct the Court's policy-making agenda. This assignment power is unique among the Chief's duties in its ability to shape the development of the law.

The Justices themselves recognize the potency of the Chief's assignment power. In the well-known exchange between Justice William O. Douglas and Chief Justice Warren E. Burger leading up to Roe v. Wade, ${ }^{3}$ Douglas criticized the assignment of the opinion to Justice Harry A. Blackmun. When the Court chose to hold Roe for reargument in the 1972 Term, Douglas drafted a dissent that lay bare what he saw as the manipulation of the Court through opinion assignment. He suggested that the Chief Justice's goal in assigning the opinion to Blackmun was "to keep control of the merits," lamenting that this strategy "makes the decisions here depend on the manipulative skills of a Chief Justice." Regardless of one's view of Chief Justice Burger's assignment in Roe, Douglas's claims certainly merit attention, as the Chief Justice may seek to influence the Court's agenda and the course of legal development through the exercise of his opinion assignment powers.

There are other effects, beyond agenda setting, that opinion assignment can have on the Court. Most notably, the choices that the Chief Justice makes in carrying out this duty affect the operation of the Court. The Justices make clear that they have expectations for how the Chief will discharge this duty. Specifically, they expect to obtain their "fair share" of assignments. Failure of a Chief Justice to equitably distribute assignments across Justices will inevitably lead to tension on the Court. Douglas's complaints about Chief Justice Burger culminated in his cry that Burger's assignment tactics in Lloyd Corp. $v$. Tanner $^{5}$ led "to a frayed and bitter Court full of needless strains and

${ }^{2}$ William H. Rehnquist, Chief Justices I Never Knew, 3 Hastings CONST. L.Q. 637, 637 (1976)

${ }^{3} 410$ U.S. 113 (1973).

${ }^{4}$ Memorandum from Justice William O. Douglas to Justice William J. Brennan (June 2, 1972) (on file with the University of Pennsylvania Law Review) [hereinafter Douglas memorandum]. Douglas, of course, ultimately withdrew this dissent and simply noted his dissent to the decision to hold Roe for reargument. Roe v. Wade, 408 U.S. 919, 919 (1972) (Douglas, J., dissenting).

${ }^{5} 407$ U.S. 551 (1972). 
quarrels." ${ }^{6}$ Equity, though critical, is not the lone expectation held by the Justices. Other norms can affect the functioning of the Courtassigning opinions, for instance, to Justices who efficiently dispatch their writing chores. As I will discuss shortly, former Chief Justice Rehnquist gave these factors, dubbed "organizational needs," great significance in his assignment decisions. ${ }^{7}$

In the pages that follow, I will discuss the agenda-setting capacity of opinion assignment. As will be evident, the Chief is able to guideor manipulate-the Court's deliberation toward options that he most favors, either producing policy gain or minimizing policy loss. This tendency is accentuated in unanimous or near-unanimous cases, but suppressed when the Chief has a fragile majority to preserve. I then discuss the Chief's pursuit of the Court's organizational needs through opinion assignment. As one sees in Justice Douglas's letter, it has often been asserted that the Chief's assignment decisions can affect the smooth operation of the Court. Finally, I offer empirical evidence of the causal factors that guided Chief Justice Rehnquist's opinion assignment decisions from the 1986 to the 1993 Terms.

\section{The ASSignMent OF MAJORITy OPINIONS}

When the Chief Justice is in the majority at the conference discussion following oral arguments, it falls to him to assign the majority opinion. ${ }^{8}$ On those occasions when the Chief is in the conference minority, the senior Associate Justice in the majority receives the responsibility of assigning the opinion. ${ }^{9}$ At the conclusion of every oral

\footnotetext{
${ }^{6}$ Draft Letter from Justice William O. Douglas to Chief Justice Warren E. Burger (May 1, 1972) [hereinafter Douglas letter] (on file with the University of Pennsylvania Law Review). This letter was written to protest Burger's practice of passing at conference before later casting a vote with the majority and then assigning the opinion. Douglas never sent this letter to Burger, but kept it in his case file.

${ }^{7}$ See Forrest Maltzman \& Paul J. Wahlbeck, May It Please the Chief? Opinion Assignments in the Rehnquist Court, 40 AM. J. POL. SCI. 421, 423-24 (1996) ("[S]tudents of the Court have proposed an 'organizational needs' model in which the Chief distributes the workload evenly among justices, assigns cases to those justices who are most efficient and encourages specialization by routinely assigning similar cases to the same justice." (citations omitted)).

${ }^{8}$ Robert J. Steamer, Chief Justice: Leadership And the Supreme Court 28 (1986).

${ }^{9}$ See Sandra Lee Wood, In the Shadow of the Chief: The Role of the Senior Associate Justice of the United States Supreme Court 15-16 (June 1994) (unpublished Ph.D. dissertation, University of Minnesota) (on file with Biddle Law Library, University of Pennsylvania) (explaining that "[o]pinion assignment (when the Chief disagrees) is certainly one" of the prerogatives of the senior Associate Justice).
} 
argument session, which lasts two weeks, the Chief Justice distributes an assignment sheet to each chambers. Chief Justice Rehnquist remarked, "When I was an associate justice I eagerly awaited the assignments." ${ }^{10}$ This assignment sheet lists the assignments made to the Justices, as well as the identity of the assignor if it is not the Chief Justice. $^{11}$

What accounts for the Chief Justice's choice in assigning opinions? In large part, political scientists explain this choice as an effort by the Chief Justice to advance his own strategic policy objectives, while meeting the Court's organizational needs. Most political scientists who study decision making on the Court point to the Justices' policy preferences as the primary factor. This common perspective assumes that Justices seek to further the legal outcomes that most closely comport with their own personal policy goals. ${ }^{12}$ The central role of policy preferences is evident in Justices' decisions to grant or deny certiorari petitions, ${ }^{13}$ in their efforts to bargain with and accom-

${ }^{10}$ William H. RehnQuist, The Supreme Court: How It Was, How It Is 296 (1987).

${ }^{11}$ If an Associate Justice assigns the opinion, his or her identity is revealed by initials next to the assignment. Associate Justices assigned $14.1 \%$ of opinions during the Burger Court, Forrest Maltzman, James F. SPRigGs II \& PAUl J. WAHLbeck, CRAFTING LAW ON THE Supreme COURT: THE Collegial Game 32 (2000), and 18.9\% during the first eight years of the Rehnquist Court, Forrest Maltzman \& Paul J. Wahlbeck, Opinion Assignment on the Rehnquist Court, 89 JUDICATURE 121, 123 (2005).

${ }^{12}$ See Lee Epstein \& JACK Knight, The Choices Justices MAKe 23 (1998) (" $[\mathrm{M}]$ ost justices in most cases pursue policy; that is, they want to move the substantive content of law as close as possible to their preferred position.”); MALTZMAN, SPRIGGS \& WAHLBECK, supra note 11, at 18 ("Supreme Court justices are strategic actors who pursue their policy preferences within the strategic constraints of a case and the Court."); Jefrrey A. Segal \& Harold J. Spaeth, The Supreme Court and the Attitudinal MODEL REVISITED 86 (2002) (arguing that the best-supported explanation for Justices' decision making is the "attitudinal model," which holds that "the Supreme Court decides disputes in light of the facts of the case vis-à-vis the ideological attitudes of the justices”).

${ }^{13}$ Certiorari decisions have been explained as a means to provide uniformity in the face of conflicting lower court decisions, S. Sidney Ulmer, The Supreme Court's Certiorari Decisions: Conflict as a Predictive Variable, 78 AM. POL. SCI. REV. 901, 910 (1984), but also as a mechanism to "pursue ... policy goals by deciding cases with maximum potential impact on political, social, or economic policy," Gregory A. Caldeira \& John R. Wright, Organized Interests and Agenda Setting in the U.S. Supreme Court, 82 AM. POL. SCI. REV. 1109, 1111 (1988), and as strategic calculations to avoid consideration of cases whose outcomes could run counter to their preferences, Gregory A. Caldeira, John R. Wright \& Christopher J.W. Zorn, Sophisticated Voting and Gate-Keeping in the Supreme Court, 15 J.L. ECON. \& ORG. 549, 566 (1999). 
modate their colleagues, ${ }^{14}$ and even in their decisions to write separate opinions. ${ }^{15}$

Opinion assignment is thus seen by those who maintain the primacy of policy seeking on the Court as a means by which the Chief Justice pursues his policy goals. As David Rohde and Harold Spaeth put it, "the rational strategy for the assignor is to assign the opinion to the justice whose views are most like his own on the issue being decided." ${ }^{\prime 6}$ This approach has two potential effects: maximizing policy gain and minimizing policy loss. When the Chief Justice's preferred outcome is in ascendancy, he can maximize policy gain by assigning the opinion either to himself or to someone whose views are similar to his own. In contrast, when the Chief's views do not hold sway at conference, he can minimize policy loss by joining the majority and assigning the opinion to the Justice in the majority who will do the least damage to legal policy, as he sees it. As Abe Fortas once wrote: "If the Chief Justice assigns the writing of the opinion of the Court to Mr. Justice $A$, a statement of profound consequence may emerge. If he assigns it to Mr. Justice $B$, the opinion of the Court may be of limited consequence." ${ }^{17}$

Conceptually, the Chief uses opinion assignment to influence the Court by using it as an agenda-setting tool. First, by selecting who will draft the majority opinion, the Chief Justice can direct which policy alternatives will receive consideration by the Court. As Justice Douglas asserted in his unpublished Roe opinion, the purpose of the confer-

${ }^{14}$ MALTZMAN, SPRigGS \& WAHLBECK, supra note 11, at 100 (asserting that the "paramount" factor shaping accommodation in opinion writing "is the ideological distance between the author and the other justices at the initial conference who expressed support for the majority position”); James F. Spriggs II, Forrest Maltzman \& Paul J. Wahlbeck, Bargaining on the U.S. Supreme Court: Justices' Responses to Majority Opinion Drafts, 61 J. POL. 485, 485 (1999) (asserting, with empirical support, that "justices decide how to respond [to majority opinion drafts] based on the effect a choice will have on securing their policy goals"); Paul J. Wahlbeck, James F. Spriggs II \& Forrest Maltzman, Marshalling the Court: Bargaining and Accommodation on the United States Supreme Court, 42 AM. J. POL. SCI. 294, 294 (1998) (finding that an examination of the number of majority opinion drafts circulated demonstrates that an author's accommodation is influenced, in part, by the Justices' bargaining tactics).

${ }^{15}$ See Paul J. Wahlbeck, James F. Spriggs II \& Forrest Maltzman, The Politics of Dissents and Concurrences on the U.S. Supreme Court, 27 AM. POL. Q. 488, 489 (1999) (arguing that "separate opinions result from the justices' pursuit of their policy preferences within both strategic and institutional constraints").

${ }^{16}$ DAVID W. Rohde \& HAROLD J. SPAETH, Supreme Court DECISION MAKING 174 (1976).

${ }^{17}$ Abe Fortas, Chief Justice Warren: The Enigma of Leadership, 84 YALE L.J. 405, 405 (1975). 
ence discussion is to determine the Court's consensus for disposing of a case, with the assigned author serving as an agent to draft an opinion consistent with that consensus. ${ }^{18}$ But the opinion author is able to direct the Court's policy-making attention to a particular policy alternative. In this way, the assigned author has the capacity to set the agenda for the Court, similar to what we see with government officials in other branches who are responsible for recommending a policy alternative from among a set. ${ }^{19}$

Second, opinion assignment enables the Chief Justice to set the Court's agenda not only by influencing which alternatives the Court considers, but also by guiding the order in which they are considered. ${ }^{20}$ Since the majority opinion is circulated before other Justices' draft dissents or concurrences, the majority author can secure preliminary commitments from her colleagues prior to their consideration of competing opinions. Moreover, an assigned author who does not favor the majority view may attempt to form a new majority by adding an alternative to the debate that may not have been considered previously by the Justices. ${ }^{21}$

\section{CONSTRAints ON AgENDA SETTING}

Even though the Chief Justice can use opinion assignment to advance his policy goals, he cannot pursue that objective without constraint. The Chief operates within limits created either by the press of other goals that he values, such as a harmonious and smoothly operating Court, or by norms that limit his ability to pursue single-mindedly

\footnotetext{
${ }^{18}$ Douglas memorandum, supra note 4, at 1-3.

${ }^{19}$ See generally Thomas H. Hammond, Agenda Control, Organizational Structure, and Bureaucratic Politics, 30 AM. J. POL. SCI. 379 (1986) (comparing agenda control in the administrative and legislative contexts).

${ }^{20}$ See William H. Riker, The ART OF POlitical Manipulation, at xi (1986) (examining how the "preferences of individual members of a group are amalgamated into a decision for the group as a whole"); WILLIAM H. RIKER, LIBERALISM AGAINST POPULISM: A CONFRONTATION BETWEEN THE THEORY OF DEMOCRACY AND THE THEORY OF SOCIAL CHOICE 169-95 (1982) (presenting an empirical analysis of the role a group's leader plays in controlling the agenda of the group's decision-making process). Some scholars of legislative behavior suggest that congressional committees are able to control outcomes through their control over the conference report, which constitutes the final proposal. See, e.g., Kenneth A. Shepsle \& Barry R. Weingast, The Institutional Foundations of Committee Power, 81 AM. POL. SCI. REV. 85, 87 (1987) (describing "proposal power" as one of "the foundation [s] of committee power").

${ }^{21}$ See Lee Epstein \& Olga Shvetsova, Heresthetical Maneuvering on the US Supreme Court, 14 J. THEORETICAL POL. 93, 96-98 (2002) (exploring the notion that adding alternatives can divide a majority).
} 
policy-based assignments. ${ }^{22}$ As the latter view suggests, the choices available to the Chief may be limited by the expectations held by his colleagues. These expectations could be shaped by formal rules, such as the number of Justices needed to form a majority, or by informal norms, like an equitable distribution of opinions. ${ }^{23}$ Another way to conceptualize the linkage of these goals is to recognize that the Chief Justice, as the Court's task leader, ${ }^{24}$ may pursue multiple goals simultaneously. ${ }^{25}$ The Chief's pursuit of nonpolicy goals will necessarily hamper his ability to maximize policy gain in each case.

As such, the Chief uses the opinion assignment power to enhance the legitimacy of the Court's opinions, promote harmony on the bench, and ensure that the Court completes its work in a timely fashion. These goals can be, and according to many studies are, met by paying heed to each Justice's share of the Court's workload, efficiency in completing her assigned opinions, and issue specialization. ${ }^{26}$ Chief

${ }^{22}$ Forrest Maltzman \& Paul J. Wahlbeck, A Conditional Model of Opinion Assignment on the Supreme Court, 57 POL. RES. Q. 551, 551 (2004).

${ }^{23}$ See JACK KNIGHT, InSTITUTIONS AND SOCIAL CONFLICT 53-66 (1992) (reviewing the role of institutions and expectations in strategic choice); JAMES G. MARCH \& JOHAN P. Olsen, Rediscovering InSTITUtions: THE ORGANiZATIONAL BASIS OF POLITICS 2126 (1989) (listing sources of rules that constrain or dictate behavior); DouGLASS C. North, Institutions, Institutional Change and Economic Performance 36-53 (1990) (discussing the role of informal and formal constraints on human interaction).

${ }^{24}$ See David J. Danelski, The Influence of the Chief Justice in the Decisional Process of the Supreme Court, in The FEDERAL Judicial SySTEM: READINGS IN PROCESS AND BEHAVIOR 147, 147-48 (Sheldon Goldman \& Thomas P. Jahnige eds., 1968) (reviewing the Chief's leadership responsibilities).

${ }^{25}$ See Lawrence Baum, The Puzzle of Judicial Behavior 23-56 (1997) (identifying the "diverse array of goals" pursued by Justices); GEORGE TSEBELIS, NESTED GAMES: RATIONAL CHOICE IN COMPARATIVE POLITICS 7-10 (1990) (arguing that rational decision makers simultaneously play multiple games based on different goals). Maltzman and Wahlbeck find empirical support for the multiple-goal perspective over the view that the Chief is constrained only by the Court's organizational needs. Maltzman \& Wahlbeck, supra note 22, at 561.

${ }^{26}$ See Saul Brenner, Issue Specialization as a Variable in Opinion Assignment on the U.S. Supreme Court, 46 J. POL. 1217, 1217-18 (1984) (enumerating the possible rationales for issue specialization); Saul Brenner \& Jan Palmer, The Time Taken To Write Opinions as a Determinant of Opinion Assignments, 72 JUDICATURE 179, 182-84 (1988) (identifying efficiency in completing earlier opinions as a significant factor in opinion assignment); Saul Brenner \& Harold J. Spaeth, Issue Specialization in Majority Opinion Assignment on the Burger Court, 39 W. POL. Q. 520, 523 (1986) (finding "evidence of specialization"); Davis, supra note 1, at 72 (examining the success of Chief Justice Rehnquist's stated goal of distributing opinions evenly); Elliot E. Slotnick, The Equality Principle $\mathcal{E}$ Majority Opinion Assignment on the United States Supreme Court, 12 POLITY 318, 318-20 (1979) (discussing the complex reasoning in opinion assignment, particularly the equality norm); Harold J. Spaeth, Distributive Justice: Majority Opinion Assignments in the Burger Court, 67 JUDICATURE 299, 300 (1984) (studying “assignment equality"). 
Justice Rehnquist claimed to pay particular attention to these considerations. On November 24, 1989, Rehnquist sent a memo to the Conference reiterating his attention to equity, but giving notice that he planned to give additional weight to the Justices' abilities to complete their assigned tasks. ${ }^{27}$ Rehnquist, despite his expressed emphasis on these considerations, was not unique. Assignments made by Chief Justices Earl Warren and Warren Burger suggest that Rehnquist's predecessors also took these factors into consideration. ${ }^{28}$

Inevitably, the organizational needs of the Court and the Chief Justice's strategic policy considerations can conflict when the Chief Justice assigns one of his colleagues the task of writing for a majority of the Court. Unlike the Chief Justice, Associate Justices who make assignments do not have to balance these competing considerations, as they do not fill the institutional leadership role that the Chief does. This leaves Associate Justices freer to advance their policy goals through opinion assignment. ${ }^{29}$ Although the conflict between the pursuit of policy goals and the safeguarding of the Court's organizational needs underlies much of the criticism of Chief Justice Burger's assignment decisions, Rehnquist publicly stated that he allowed the organizational needs of the Court to trump strategic policy considerations. $^{30}$ While some differences emerge from studies of different Chief Justices, they tend to weigh factors in a similar manner.

\section{OPINION ASSIGNMENT AS AgENDA SETTING}

The capacity of opinion assignment for agenda setting, and the Chief Justice's use of it to minimize policy loss, is vividly illustrated in the 1972 case of Loper $v$. Beto. ${ }^{31}$ In 1969, Otis Loper filed one of "a steady succession of petitions" for habeas corpus to challenge his 1947

\footnotetext{
${ }^{27}$ Memorandum from Chief Justice William H. Rehnquist to the Conference, Policy Regarding Assignments (Nov. 24, 1989) [hereinafter Rehnquist memorandum] (on file with the University of Pennsylvania Law Review) ("[I]t only makes sense in the assignment of additional work to give some preference to those who are 'current' with respect to past work.").

28 See MAltzMAn, SpRiggs \& WAHLBeck, supra note 11, at 35-53 (identifying and quantifying the factors used in assignments by Chief Justices Burger and Warren); Maltzman \& Wahlbeck, supra note 22, at 558 (revealing that expertise, equity, ideology, and efficiency played into the assignment decisions of each Chief Justice).

${ }^{29}$ MALTZMAN, SPRIGGS \& WAHLBECK, supra note 11, at 40.

${ }^{30}$ See REHNQUIST, supra note 10, at 297 ("I take into consideration the extent to which the various justices are current [in their workload].").

${ }^{31} 405$ U.S. 473 (1972).
} 
conviction for raping his stepdaughter. ${ }^{32}$ At issue was whether "the use of prior, void convictions for impeachment purposes deprive[s] a criminal defendant of due process of law where their use might well have influenced the outcome of the case." ${ }^{33}$ At his 1947 trial, Loper testified on his own behalf, maintaining that he had not assaulted his stepdaughter. During cross-examination, Loper conceded that he had four felony convictions between 1931 and 1940. The jury found Loper guilty and sentenced him to fifty years in prison. In 1969, Loper claimed that the convictions that were used to impeach his testimony had been obtained without the benefit of counsel. This claim was supported by his sworn testimony and court records. Although his petition for habeas corpus was denied by the District Court for the Southern District of Texas, a decision which was later affirmed by the Fifth Circuit Court of Appeals, the Supreme Court granted certiorari to hear Loper's appeal.

At conference, according to the records of several retired Justices, including Justice William J. Brennan, Jr., the conference expressed support for three distinct dispositions: affirm the lower court (Rehnquist), remand for resentencing (Burger and Powell), and reverse the lower courts and remand for a new trial (Brennan, Stewart, White, Marshall, and Brennan). ${ }^{35}$ Douglas was absent from the arguments and did not cast a conference vote, although he later voted to remand for a new trial.

If Brennan's and Powell's docket sheets are an accurate record of the conference vote, the duty to assign the task of writing the majority opinion would fall to Justice Brennan as the senior Justice in the conference majority. However, the assignment sheet for the January argument session that Chief Justice Burger circulated on January 25, 1972, indicated that Burger assigned himself this opinion. In particular, Burger assigned this opinion as a per curiam to dismiss the case as

\footnotetext{
${ }^{32}$ Loper v. Beto, 440 F.2d 934, 936 (5th Cir. 1971), vacated, 405 U.S. 473 (1972). Loper was paroled after serving fifteen years of his sentence. With his release, he received permission to move to Mississippi. Loper's parole was cut short, however, following his arrest for stealing a car. Before Loper could be moved back to the Texas Department of Corrections, he escaped from the Carthage, Mississippi, jail and remained at large for more than a year. After his eventual capture, he was taken to Texas where he was again incarcerated. Id.

${ }^{33}$ Loper v. Beto, 404 U.S. 821 (1971) (mem.), granting cert. to 440 F.2d 934 (5th Cir. 1971).

${ }^{34}$ The facts of Loper were derived from the Supreme Court's opinion. 405 U.S. at 474-80.

${ }^{35}$ Letter from Justice William J. Brennan to Chief Justice Warren E. Burger (Jan. 26, 1972) (on file with the University of Pennsylvania Law Review).
} 
improvidently granted (DIG). Brennan responded the next day with his letter recounting the vote that he had recorded in his personal notes, and stating that as the senior Justice in the conference majority, he would assign the opinion to Potter Stewart. He said, "I had supposed in that circumstance it would fall to me to assign the opinion. The assignment sheet, however, shows that you have assigned it to yourself to write an opinion dismissing [the appeal] as improvidently granted. No one seems to have cast that vote." ${ }^{36}$ Justice Stewart also wrote to the Chief to corroborate Brennan's version of the conference vote: "My notes do not show that anyone at Conference voted to dismiss this case as improvidently granted." ${ }^{37}$

While Chief Justice Burger acknowledged the confusion over the assignment, he still maintained that a "DIG' might be possible." ${ }^{38} \mathrm{He}$ concluded his memo by claiming, "Since I voted to reverse or 'DIG' I will make the assignment for whichever of those two finally commands a majority." ${ }^{39}$ There is no evidence in the notes taken by Justices Brennan, Blackmun, or Powell to confirm Burger's assertion. Each recorded his preference for remanding the case for resentencing. Blackmun alone mentioned a DIG in his conference notes, quoting Byron White who was "sorry we took case. But painted into corner. Clearly [a] miscarriage... [could] DIG." ${ }^{40}$ White decided, however, that precedent dictated a new trial.

There are two ways in which the Chief attempted to control the agenda in Loper: first, by using sophisticated voting to join the majority and select an opinion author who would minimize policy loss, and second, by proposing an alternative to the view supported by the majority. Burger perhaps sought to minimize policy loss by casting a sophisticated vote. In a multi-stage voting process, a sophisticated vote is one in which a person votes against her most preferred alternative in the first stage in order to obtain a better outcome in the second and final stage. As Calvert and Fenno described it in the congressional setting, sophisticated voting occurs "when a legislator votes against an amendment that he or she favors in principle, in order to improve

${ }^{36}$ Id.

37 Letter from Justice Potter Stewart to Chief Justice Warren E. Burger (Jan. 26, 1972) (on file with the University of Pennsylvania Law Review).

${ }^{38}$ Memorandum from Chief Justice Warren E. Burger to the Conference (Jan. 26, 1972) (on file with the University of Pennsylvania Law Review).

Id.

${ }^{40}$ Harry A. Blackmun, Conference Notes (Jan. 1972) (on file with the University of Pennsylvania Law Review). 
chances for passage of the bill itself." ${ }^{41}$ In the Supreme Court, sophisticated voting occurs when a Justice votes for what she views as a suboptimal alternative at conference in order to obtain a more favorable final outcome. Chief Justice Burger had been previously accused of casting "phony votes" whereby, as one Justice put it, he voted "with the majority so as to assign the opinion, and then he ends up in dissent." 42

In the absence of a clear statement of his sincere preference in Loper, one must divine whether Burger's conference vote was based on insincere preferences on the basis of his voting record in similar cases. In other right-to-counsel cases, Burger had supported the prosecution $83.9 \%$ of the time and had always supported the government in cases involving prejudicial statements like those involved in Loper. $^{43}$ Rehnquist, the lone Justice who supported affirming the lower courts in Loper, favored the government in $86.0 \%$ of right-to-counsel cases. In contrast, for instance, Justice Stewart, to whom Justice Brennan sought to assign the decision in Loper, voted for the accused in $69.7 \%$ of the Court's right-to-counsel cases during his tenure on the bench. Armed with these statistics, one might reasonably conclude that Chief Justice Burger cast his vote to remand not because he sincerely preferred this outcome, but rather because he sought to guide the Court through opinion assignment to a less damaging decision on the merits. In Loper, Burger could assign the case to one of several Justices who might be counted on to write a narrow opinion. In hindsight, Harry Blackmun, who switched to the dissent, or Byron White, who ultimately concurred in the result, would have provided a more acceptable opinion to Burger than would the remaining majority Jus-

${ }^{41}$ Randall L. Calvert \& Richard F. Fenno, Jr., Strategy and Sophisticated Voting in the Senate, 56 J. POL. 349, 349 (1994). Other scholars have examined sophisticated voting in Congress. See, e.g., Jeffrey A. Jenkins \& Michael C. Munger, Investigating the Incidence of Killer Amendments in Congress, 65 J. POL. 498, 499 (2003) (discussing the use of sophisticated voting in response to the introduction of a "killer amendment"); Andrew D. Martin, Congressional Decision Making and the Separation of Powers, 95 AM. POL. SCI. REV. 361, 364-66 (2001) (identifying scenarios in which sophisticated voting increases); Craig Volden, Sophisticated Voting in Supermajoritarian Settings, 60 J. POL. 149, 151 (1998) (arguing that sophisticated voting rises where supermajorities are required to override a veto or end a filibuster).

${ }^{42}$ Bernard Schwartz, Decision: How the Supreme Court Decides Cases 45 (1996).

${ }^{43}$ These preference indicators are derived from Harold J. Spaeth, The S. Sidney Ulmer Project: U.S. Supreme Court Databases, The Original United States Supreme Court Judicial Database 1953-2005 Terms, http://www.as.uky.edu/polisci/ulmerproject/ sctdata.htm (last visited Mar. 21, 2006). 
tices. $^{44}$ When this gambit failed, however, Chief Justice Burger relented and released the prerogative to assign the opinion to Douglas, who cast a vote to reverse by memo on January $27,1972 .{ }^{45}$

Second, the Chief Justice used the opinion assignment to introduce an alternative disposition. ${ }^{46}$ Although three distinct positions gained adherents at conference, Chief Justice Burger assigned the opinion in Loper for a fourth disposition. This undoubtedly was his attempt to divide the otherwise solid majority in favor of remanding the case for a new trial. In essence, a strategic leader can propose a new alternative that will introduce instability in the form of a voting cycle. $^{47}$ If a vote had pit the Justices supporting remand for resentencing against those favoring remand for a new trial, the conference would have supported a new trial. But it is possible, as Burger claimed, that the DIG disposition might have defeated the remand for a new trial disposition. This voting instability appealed to Burger as it allowed him to minimize his presumed policy loss if a majority of his colleagues would find a DIG preferable to the outcome they initially supported at conference.

The effect on voting stability of adding an alternative is apparent in the Justices' preference orderings. Assume that Burger had the following preference orderings over the two dominant conference positions:

Remand for Resentencing > Remand for New Trial

${ }^{44}$ Blackmun supported the prosecution in $51.2 \%$ of right-to-counsel cases, while White sided with the government in $70.8 \%$ of these cases.

${ }^{45}$ See Letter from Justice William O. Douglas to Chief Justice Warren E. Burger (Jan. 27, 1972) (on file with the University of Pennsylvania Law Review) (voting to reverse despite having abstained at conference); Letter from Chief Justice Warren E. Burger to Justice William O. Douglas (Jan. 31, 1972) (on file with the University of Pennsylvania Law Review) (confirming Douglas's vote and indicating that Douglas should assign the opinion); Letter from Justice William O. Douglas to Chief Justice Warren E. Burger (Jan. 31, 1972) (on file with the University of Pennsylvania Law Review) (allowing the earlier assignment of the opinion to Justice Stewart to stand).

${ }^{46}$ Other Justices can propose alternatives in opinions they circulate to the Court, but the Chief Justice can initiate this switch with the opinion assignment. For instance, Justice Brennan's first draft for the majority in Pennsylvania v. Muniz, 496 U.S. 582 (1990), was accompanied by a cover letter that said, "Although I originally voted to affirm the judgment of the state court, I now believe that the proper disposition of the case, given our conclusions, is to vacate the judgment and remand for further proceedings. Accordingly, I have styled the draft opinion in this manner." Memorandum from Justice William J. Brennan to the Conference (May 31, 1991) (on file with the University of Pennsylvania Law Review).

${ }^{47}$ See Epstein \& Shvetsova, supra note 21, at 98 (discussing how the Chief Justice can create a cycle of preferences so as to control the agenda). 
In contrast, the majority's preference ordering was:

\section{Remand for New Trial > Remand for Resentencing}

White's comments at conference, however, suggested that another alternative, a DIG, might be able to siphon votes from the majority. White made clear that his preference ordering was:

$$
D I G>\text { Remand for New Trial > Remand for Resentencing }
$$

Although White would support a remand for a new trial over a remand for resentencing, it was reasonable to conclude that he might be persuaded to cast a vote to DIG the case.

In light of the controversy over Burger's assignment, the conference discussed this case again on January 27. At that time, according to Blackmun's notes, several Justices voiced support for a DIG, including the Chief Justice and Powell. ${ }^{48}$ Rehnquist continued to assert that his preference was to affirm the lower court. Stewart argued that a "DIG would be the last thing to do" and that "we are obligated to decide" the case. White stated that "I voted to deny. . . . But we did grant it. Our decision-reverse." ${ }^{49}$ Rehnquist's dissenting opinion, which concluded with his stated preference for a DIG, attracted the support of Justice Blackmun. Blackmun switched from his conference vote to remand for a new trial to Rehnquist's dissent, which supported either a DIG or an affirmance of the lower court. Ultimately, Rehnquist's

\footnotetext{
${ }^{48}$ See Blackmun, supra note 40 (recording that Burger voted to "[e]ither DIG or $\mathrm{R}$ [everse] \& remand" and that Powell "c[oul]d DIG").

${ }^{49} I d$. In following this course of action, White adhered to a strict interpretation of the Rule of Four and DIGs. See Scott A. Hendrickson, To DIG or Not To DIG: Using DIGs to Examine Supreme Court Decision Making and Agenda Setting 8 n.15 (Working Paper 2003), http://www.artsci.wustl.edu/ sahendri/workingpaper/apsa03.pdf (noting that White "digged certiorari over the dissent of the only four justices ... who had voted to grant" it in Triangle Improvement Council v. Ritchie, 402 U.S. 497 (1971)). For New York v. Uplinger, 467 U.S. 246 (1984) (per curiam), Justice John Paul Stevens wrote a private letter to Justice Brennan saying that he could join Brennan's per curiam opinion dismissing the case as improvidently granted if one of the original four votes to grant joined as well. Stevens added, "I am most reluctant, however, to join this kind of disposition over the dissent of the four Members of the Court who voted to grant the case, even though, as you know, I think this was a particularly unwise grant." Letter from Justice John Paul Stevens to Justice William J. Brennan (Mar. 1, 1984) (on file with the University of Pennsylvania Law Review). Interestingly, White dissented in Uplinger, claiming that the case was properly before the Supreme Court and should be addressed. He concluded that a DIG was not the "proper course." 467 U.S. at 252 (White, J., dissenting). In Loper, there were seven sitting Justices when certiorari was granted on the votes of Justices Douglas, Brennan, Stewart, and Marshall.
} 
opinion won the support of four Justices, but not of Justice White, who wrote an opinion concurring in the result.

\section{Conditional EfFects of Agenda Setting}

The Chief Justice does not uniformly assign opinions to his allies, as the agenda-setting argument would hypothesize. Indeed, there are instances where a strategic Chief will signal a retreat from this goal. Most notably, the Chief may reach beyond his usual allies when the majority is particularly fragile. The literature has maintained that the Chief Justice, when facing a narrow majority, may be more likely to assign the opinion to a moderate member of the Court. Two distinct reasons have been given for this tactic: first, this would avoid the breakup of the Chief's majority coalition, and second, it may encourage dissenters to join the opinion of the Court. ${ }^{50}$ By assigning this opinion to a more ideologically distant Justice in an effort to maintain a majority for his preferred disposition, the Chief minimizes policy loss.

The risk associated with assigning an opinion to a Justice close to one of the ideological extremes was evident in United States v. Glaxo Group Ltd. ${ }^{51}$ Glaxo concerned an antitrust claim against British drug manufacturers stemming from their sublicensing agreements with American companies to sell their product while prohibiting bulk sales of their drug without prior approval. The District Court for the District of Columbia ruled in favor of the government, finding that these bulk sales restraints were a violation of the Sherman Act. As a remedy, the government sought to invalidate the underlying patents, but the district court denied this relief because the companies did not rely on their patents to defend the antitrust claim. ${ }^{52}$

${ }^{50}$ See Danelski, supra note 24, at 156-57 (explaining how the Chief's assignments may influence the disposition of a case). Some have found that this strategy may not work, as moderate Justices are not more likely to maintain the original coalition than their more extreme colleagues, see, e.g., Saul Brenner \& Harold J. Spaeth, Majority Opinion Assignments and the Maintenance of the Original Coalition on the Warren Court, 32 AM. J. POL. SCI. 72, 80 (1988) (summarizing the results of an empirical study of Supreme Court coalitions), and dissenters are not more likely to join a moderate's opinion, see Saul Brenner et al., Increasing the Size of Minimum Winning Original Coalitions on the Warren Court, 23 POLITY 309, 315 (1990) (describing a bivariate analysis of the Warren Court coalitions and how often moderate opinions are joined by original dissenters).

${ }_{51}^{51} 410$ U.S. 52 (1973).

${ }^{52} I d$. at 56. 
After the Supreme Court heard arguments in the case on November 9, 1972, six Justices voted at conference to affirm the district court's decision. Since the Chief Justice and the two most senior Associate Justices, Douglas and Brennan, formed the conference minority, the power to assign the opinion fell to Justice Stewart. Stewart informed Chief Justice Burger on November 13, 1972, that "I have asked Bill Rehnquist to write the opinion for the Court in this case." ${ }^{53}$

This choice, according to much of the literature, was not the optimal move; instead, opinion writing should have been delegated to the Justice at the ideological center of the Court, that is, the median Justice. In 1972, the Court median in economic cases was Stewart himself. $^{54}$ Instead, as seen in Figure 1, Stewart assigned the opinion to one of the conference majority Justices closest to the conservative pole, Justice Rehnquist. The risk in assigning the opinion to one of these Justices was that it could alienate the Justices closest to the dissenters, prompting them to abandon their conference position in favor of the minority view. ${ }^{55}$ The conference majority Justices who were most at risk of defection were Justice White, who disagreed with Rehnquist in economic cases about $29 \%$ of the time, and Justice Marshall, who supported the conservative, or pro-business, position in less than half of the Court's previous economic cases. The strategically wise assignment would have been one of these Justices.

${ }^{53}$ Letter from Justice Potter Stewart to Chief Justice Warren E. Burger (Nov. 13, 1972) (on file with the University of Pennsylvania Law Review).

${ }_{54}$ As a measure of ideology, I used the data from Spaeth, supra note 43, to calculate the percentage of cases in which a Justice voted in a liberal direction in each value area in Terms prior to the one in which the case was considered. I estimate a new Justice's ideology following the method discussed in Timothy R. Johnson, James F. Spriggs II \& Paul J. Wahlbeck, Passing and Strategic Voting on the U.S. Supreme Court, 39 LAW \& SOC'Y REV. 349, 361-62 (2005) (modeling future voting behavior on Spaeth's data and distance from the Court's median).

${ }^{55}$ Studies of the fluidity of Justices' votes between conference and the final recorded vote on the merits show that a Justice is more likely to change her vote when the dissent is closer to her own views than the majority opinion author. Forrest Maltzman \& Paul J. Wahlbeck, Strategic Policy Considerations and Voting Fluidity on the Burger Court, 90 AM. POL. SCI. REV. 581, 588 (1996). 
Figure 1: United States v. Glaxo in Ideological Space ${ }^{56}$

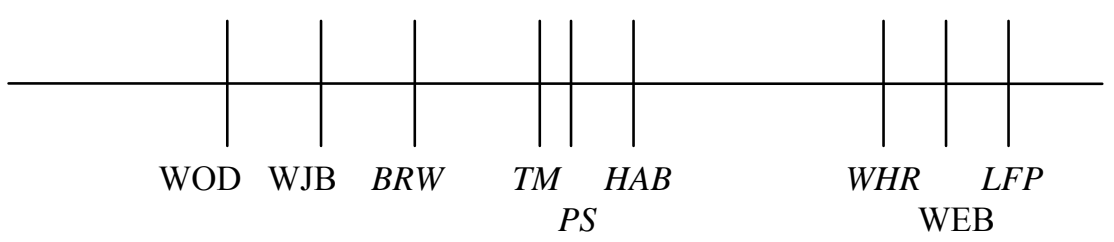

The consequence of this strategic error was apparent as soon as Justice Rehnquist's draft majority opinion circulated on November 22, 1972. Justice White responded by remarking that he had "second thoughts" and was "considering a dissent with respect to the Government's authority in specified situations to demonstrate the invalidity of a patent." ${ }^{57}$ After White circulated his dissent a week later, Justice Marshall added his voice to the mounting opposition to Rehnquist's draft. Marshall wrote Rehnquist on November 28, 1972, stating that he was "somewhere between Douglas and White. I am sorry I cannot join your opinion insofar as remedy is concerned." $"$ The day after White's proposed dissent was circulated, Marshall joined White's dissent.

With these two defections, the ranks of the Justices opposing Rehnquist's opinion had swollen from the three original dissenters to a majority of five Justices. Chief Justice Burger promptly responded to this development by writing a memorandum to the conference: "It appears that the resolution of this case is undergoing some evolution and that Mr. Justice Rehnquist's proposed opinion does not enlist a majority." ${ }^{59}$ He then reassigned the majority opinion to Justice White. Later, and without comment, Justice Powell also switched sides and joined White's opinion on December 27, 1972, making the final tally six to three to reverse the lower court's decision. ${ }^{60}$

${ }^{56}$ Note: Conference majority Justices in italics.

${ }^{57}$ Letter from Justice Byron R. White to Justice William H. Rehnquist (Nov. 27, 1972) (on file with the University of Pennsylvania Law Review).

${ }^{58}$ Letter from Justice Thurgood Marshall to Justice William H. Rehnquist (Nov. 28, 1972) (on file with the University of Pennsylvania Law Review).

${ }^{59}$ Memorandum from Chief Justice Warren E. Burger to the Conference (Dec. 7, 1972) (on file with the University of Pennsylvania Law Review).

${ }^{60}$ United States v. Glaxo, 410 U.S. 52, 53 (1973). 
A few years later, a chastened Justice Stewart wrote to Chief Justice Burger when assigning opinions in Tully $v$. Griffin, Inc. ${ }^{61}$ and United States v. Foster Lumber $\mathrm{Co}^{62}$ following close conference votes:

I was asked to assign the opinions in both of these cases, which were the subjects of closely divided Conference votes. Having in mind my dismal track record as an assignor (see, e.g., U.S. v. Glaxco [sic] Group Ltd., 410 U.S. 52), I have decided to undertake both opinions myself, rather than inflict them upon any of my colleagues in the fragile majorities. ${ }^{63}$

Of course, had Stewart assigned Glaxo to himself, the Court median in economic cases in 1972, he very well might have avoided the eventual debate and switch in outcomes.

\section{ADDITIONAL CONDITIONS}

Not only is the effect of agenda-setting policy calculations conditioned by the size of the conference majority, but Chief Justices are apt to place greater weight on policy views when assigning cases that promise to make a significant contribution to public or legal policy. Underlying this weighting is the assumption that cases are not of equal worth in the eyes of the Justices. Justice Powell once complained to Chief Justice Burger that he had been assigned "two lemons last months [sic] (two Social Security statutory construction cases)." In contrast, Rehnquist commented that, as an Associate Justice, he "eagerly awaited the assignments" as "the office offers no greater reward than the opportunity to author an opinion on an important

61429 U.S. 68 (1976)

429 U.S. 32 (1976).

${ }^{63}$ Letter from Justice Potter Stewart to Chief Justice Warren E. Burger (Oct. 8, 1976) (on file with the University of Pennsylvania Law Review).

${ }^{64}$ Memorandum from Justice Lewis F. Powell to Chief Justice Warren E. Burger (Mar. 25, 1986) [hereinafter Powell memorandum] (on file with the University of Pennsylvania Law Review). Chief Justice Burger sent a note to Justice Powell during arguments in $U A W v$. Brock, 477 U.S. 274 (1986), criticizing Powell's vote to grant certiorari. During oral arguments, Burger passed Powell a note saying, "You can pay $\$ 25.00$ to the Coffee Fund-for taking this case. If it turns out 'right' you can work out your fine by writing it!” Memorandum from Chief Justice Warren E. Burger to Justice Lewis F. Powell (Mar. 25, 1986) (on file with the University of Pennsylvania Law Review). Powell responded by writing a check for $\$ 25$ and passing it to Burger with a note that said, "I did 'blow it' by voting to grant. I'll pay the $\$ 25$ (check enclosed) on assurance the case will not be assigned to me! After all you gave me two lemons last months [sic] (two Social Security statutory construction cases). Also I'm still hurting from having to write Matsushita [Electric Industrial Co. v. Zenith Radio Corp., 475 U.S. 574 (1986) ].” Powell memorandum, supra. Chief Justice Burger refused the check. 
point of constitutional law." ${ }^{65}$ Research shows that the Chief Justice gives greater weight to a colleague's ideology in politically salient cas$\mathrm{es}^{66}$ and disproportionately self-assigns legally salient cases. ${ }^{67}$ The agenda-setting explanation would maintain that assignments to allies in these cases serve the Chief Justice by ensuring policy gains in these especially important cases.

\section{ORGANIZATIONAL CONSTRAINTS}

While opinion assignment offers the Chief Justice a potent weapon to shape the law, most recent Chief Justices have asserted that they eschewed those concerns and attempted to assign opinions fairly to their colleagues. Chief Justice Earl Warren remarked, "I do believe that if [the assignment process] wasn't done with regard to fairness, it could well lead to great disruption in the Court." ${ }^{38}$ Rehnquist maintained that he tried "to be as evenhanded as possible as far as numbers of cases assigned to each justice." ${ }^{69}$ The Chief Justice does not have unbounded power to pursue his policy-based interests. The Chief confronts the needs of the Court as an organization.

One of the principal constraints on the Chief Justice's assignments is the norm to equitably distribute opinions to the Justices. Chief Justice Rehnquist claimed that during his first three Terms as Chief, "the principal rule I have followed in assigning opinions is to give everyone approximately the same number of assignments of opinions for the Court during any one Term." ${ }^{70}$ Although Rehnquist explicitly mentioned his benchmark as equity within the Term, an intermediate equity goal is the distribution of opinions from each argument session.

${ }^{65}$ REHNQUIST, supra note 10 , at 296.

66 MAltzMAn, SPRigGS \& WAHLBECK, supra note 11, at 35-36; Maltzman \& Wahlbeck, supra note 22, at 552; David W. Rohde, Policy Goals, Strategic Choice and Majority Opinion Assignments in the U.S. Supreme Court, 16 MIDWEST J. POL. SCI. 652, 655 (1972); Elliot E. Slotnick, Who Speaks for the Court? Majority Opinion Assignments from Taft to Burger, 23 AM. J. POL. SCI. 60, 60-62 (1979); S. Sidney Ulmer, The Use of Power in the Supreme Court: The Opinion Assignments of Earl Warren, 1953-1960, 19 J. PUB. L. 49, 67 (1970).

67 Saul Brenner, The Chief Justices' Self Assignment of Majority Opinions in Salient Cases, 30 Soc. SCI. J. 143, 144 (1993); Maltzman \& Wahlbeck, supra note 22, at 552; Rohde, supra note 66, at 656; Elliot E. Slotnick, The Chief Justices and Self-Assignment of Majority Opinions, 31 W. POL. Q. 219, 219 (1978).

68 Anthony Lewis, A Talk with Warren on Crime, the Court, the Country, N.Y. TIMES MAG., Oct. 19, 1969, at 130.

${ }^{69}$ REHNQUIST, supra note 10, at 297.

${ }^{70}$ Memorandum from Chief Justice William H. Rehnquist to the Conference, Policy Regarding Assignments (Nov. 24, 1989) (on file with the University of Pennsylvania Law Review). 
The Justices' correspondence is replete with references to their desire to maintain balance across the chambers within an assignment cycle. Almost apologetically, Chief Justice Burger wrote a cover letter to the conference accompanying the assignments, stating that " $[\mathrm{w}]$ ith only seven cases, there was not enough to 'go around." 71 The desire to maintain equity within an assignment cycle is also seen in the Justices' efforts to trade assignments if a Justice received an assignment that she could not complete. When Justice Powell received the assignment in Vance v. Universal Amusement Co., ${ }^{72}$ he announced that, given his position favoring dismissal for want of an adequately presented federal question, he could not write a per curiam opinion for the Court without also authoring a dissent. Burger replied, "I accept your 'abdication'. However there is no occasion for a 'trade' since there is no comparable canine special in the last week's 'litter'. I will ask someone else to try to deal with this critter." ${ }^{73}$ In Fiallo v. Bell, ${ }^{74}$ another case where a trade was not feasible, Burger wrote that he would make it up "on the "next round.",75

In addition to concerns about equity, Chief Justices have expressed an interest in facilitating the timely completion of the Court's workload. The Justices are acutely aware of the "June crunch," when the Court finishes its work on cases heard during the Term-many memos among the Justices allude to the coming end of the Court's Term. As the Court's administrative leader, the Chief Justice has responsibility for prodding his colleagues to fulfill their obligations before the end of June. Chief Justice Burger once prompted his colleagues, "This is the time of the year when we remind ourselves of the May 31 'target date' to have all assigned opinions in circulation." ${ }^{76}$

This constraint affects the Chief Justices' opinion assignment practices as they seek "to avoid the annual 'June crunch,' at which time so much of our work seems to pile up." 77 In a memorandum to the Conference on November 24, 1989, Chief Justice Rehnquist informed his

${ }^{71}$ Memorandum from Chief Justice Warren E. Burger to the Conference (Oct. 15, 1977) (on file with the University of Pennsylvania Law Review).

72445 U.S. 308 (1980).

${ }^{73}$ Letter from Chief Justice Warren E. Burger to Justice Lewis F. Powell (Dec. 10, 1979) (on file with the University of Pennsylvania Law Review).

74430 U.S. 787 (1977).

${ }^{75}$ Memorandum from Chief Justice Warren E. Burger to the Conference (Dec. 13, 1976) (on file with the University of Pennsylvania Law Review).

${ }^{76}$ Memorandum from Chief Justice Warren E. Burger to the Conference (May 10, 1983) (on file with the University of Pennsylvania Law Review).

77 REHNQUIST, supra note 10 , at 297. 
colleagues that he would "put more weight than I have in the past on" whether a chambers has overdue uncirculated majority or dissenting opinions or delinquent votes. ${ }^{78}$ Although Rehnquist moved such efficiency to the forefront of his assignment calculus, other Chief Justices were likewise motivated by their colleagues' propensity to complete opinion-writing chores quickly. In a study of assignments made by the Chief Justice between 1953 and 1990, Maltzman and Wahlbeck found that selections by these Chiefs were explained, in part, by which Justice could promptly complete opinion writing, especially as the end of the Court's term approached. ${ }^{79}$

\section{ChIEF JUSTICE REHNQUist's OPINION ASSIGNMENTS}

Whereas Chief Justice Burger was often criticized for trying to impose his will on the Court through opinion assignments, ${ }^{80}$ research indicates that Chief Justice Rehnquist was not motivated by ideological concerns in his assignment decisions. A study of assignments between 1987 and 1989 reveals that Rehnquist did not systematically assign opinions to his closest allies. ${ }^{81}$ In contrast, the study of assignments from the 1953 to the 1990 Terms found empirical support for the supposition that Chief Justices favor their allies. ${ }^{82}$ The question that I now address is whether Rehnquist sought to direct the Court and its doctrinal development through the exercise of this prerogative.

I used the files maintained by Justice Blackmun, currently housed at the Library of Congress, to identify Chief Justice Rehnquist's assignments during the Terms between 1986 and 1993. The papers contain the assignment sheets circulated by both Chief Justices Burger and Rehnquist. These assignment sheets are the original sources through which Justices received their writing assignments. If one were to simply consult the final opinions to ascertain who assigned the majority opinion or who received the assignment, one would introduce significant measurement error. Looking at the assignors, first, if one assumed the opinion was assigned by the most senior Justice in the final majority coalition, one would be wrong in the $23.9 \%$ of cases in which someone other than Rehnquist actually assigned the opinion even though Rehnquist ultimately joined the majority coalition. Sec-

78 Id.

${ }^{79}$ Maltzman \& Wahlbeck, supra note 22, at 552-53.

${ }^{80}$ Maltzman \& Wahlbeck, supra note 7, at 439.

${ }^{81}$ Id. at 421 .

${ }^{82}$ Maltzman \& Wahlbeck, supra note 22, at 558. 
ond, one would be mistaken in assuming that the eventual majority author received the initial assignment, in $5.2 \%$ of the cases assigned by the Chief Justice. Thus, rather than examine the published opinions to attribute assignments, I limit the following analysis to those Terms for which original assignment sheets are available.

According to the assignment sheets found in Blackmun's papers, Rehnquist assigned a substantial share of the majority opinions during this portion of his tenure as Chief, as seen in Table 1. Justice Brennan assigned the most majority opinions among Associate Justices, assigning more than $10 \%$ of all opinions for the 1986-1993 period, despite his retirement following the 1989 Term. Table 2 presents the number of assignments made to each Justice by Chief Justice Rehnquist or an Associate Justice. As that table shows, Chief Justice Rehnquist selfassigned frequently, retaining more assignments for himself than he delegated to any other single Justice. The other Justices who were regular beneficiaries of Rehnquist assignments were White, Stevens, O'Connor, and Scalia. These data also show that Justices Brennan, White, Blackmun, and Stevens received numerous assignments from the Court's Associate Justices.

Table 1: Justices Who Assigned Majority Opinions: 1986-1993 Terms

\begin{tabular}{lcc} 
Assigning Justice & Number Assigned & \% of Total \\
\hline \hline William H. Rehnquist & 791 & 81.0 \\
William J. Brennan, Jr. & 102 & 10.5 \\
Byron R. White & 41 & 4.2 \\
Thurgood Marshall & 1 & 0.1 \\
Harry A. Blackmun & 27 & 2.8 \\
John Paul Stevens & 10 & 1.0 \\
Sandra Day O'Connor & 4 & 0.4 \\
\hline Total & 976 & 100.0
\end{tabular}


Table 2: Justices Who Received Assignments: 1986-1993 Terms

\begin{tabular}{lrrrrr} 
Justice & $\begin{array}{l}\text { Number of } \\
\text { Assignments Made } \\
\text { by Rehnquist }\end{array}$ & $\begin{array}{l}\text { Number of } \\
\text { Assignments Made by } \\
\text { Associate Justices }\end{array}$ & $\begin{array}{l}\text { Percent of } \\
\text { Eligible } \\
\text { Assignments }\end{array}$ \\
\hline \hline William H. Rehnquist & 123 & $(15.5)$ & 0 & $(0.0)$ & 15.4 \\
William J. Brennan, Jr. & 26 & $(3.3)$ & 37 & $(20.0)$ & 18.5 \\
Byron R. White & 91 & $(11.5)$ & 23 & $(12.4)$ & 15.6 \\
Thurgood Marshall & 58 & $(7.3)$ & 14 & $(7.6)$ & 18.0 \\
Harry A. Blackmun & 68 & $(8.6)$ & 25 & $(13.5)$ & 14.2 \\
Lewis F. Powell & 18 & $(2.3)$ & 2 & $(1.1)$ & 15.8 \\
John Paul Stevens & 89 & $(11.3)$ & 27 & $(14.6)$ & 18.1 \\
Sandra Day O'Connor & 106 & $(13.4)$ & 14 & $(7.6)$ & 15.8 \\
Antonin Scalia & 89 & $(11.3)$ & 14 & $(7.6)$ & 13.4 \\
Anthony M. Kennedy & 61 & $(7.7)$ & 16 & $(8.6)$ & 12.1 \\
David H. Souter & 32 & $(4.0)$ & 7 & $(3.8)$ & 11.7 \\
Clarence Thomas & 26 & $(3.3)$ & 2 & $(1.1)$ & 12.3 \\
Ruth Bader Ginsburg & 4 & $(0.5)$ & 4 & $(2.2)$ & 12.3 \\
\hline Total & 791 & $(100.0)$ & 185 & $(100.1)$ &
\end{tabular}

Even though Chief Justice Rehnquist disproportionately assigned opinions to his allies, as seen in Table $2,{ }^{83}$ bivariate analysis of Rehnquist's assignment practices does not support the basic premise of the agenda-setting explanation. That is, the Chief Justice apparently did not assign opinions to shape the development of the law in line with his preferences. A difference in means test, presented in Table 3, demonstrates that Justices who received writing assignments from the Chief were not significantly closer to the Chief ideologically than those Justices who were passed over for the task. ${ }^{84}$ Perhaps, however, Chief Justice Rehnquist made efforts to set the agenda only in politically salient cases. ${ }^{85}$ In fact, as seen in Table 3 , the Chief did as-

\footnotetext{
${ }^{83}$ Justice Stevens is the lone exception.

${ }^{84}$ I measured ideological distance by taking the absolute difference between the assignor's ideology and the ideology of Justices in the conference majority, as measured by the percentage of a Justice's votes that were liberal in an area of law. Data were taken from Spaeth, supra note 43.

${ }^{85}$ Politically salient cases are those cases that were reported on the front page of The New York Times. See Lee Epstein \& Jeffrey A. Segal, Measuring Issue Salience, 44 AM. J. POL. SCI. 66, 72-76 (2000) (proposing a New York Times measure of salience for Su-
} 
sign politically salient cases to Justices who were significantly closer to him in ideology than others in the conference majority. I do not, however, find a bivariate relationship supporting the strategic assignment of close cases ${ }^{86}$ to Justices relatively distant from the Chief in order to maintain the majority coalition. ${ }^{87}$

\section{Table 3: Difference in Means Tests for Explanations of Rehnquist's Opinion Assignments}

\begin{tabular}{|c|c|c|c|c|}
\hline Variable & $\begin{array}{l}\text { Assigned } \\
\text { Opinion }\end{array}$ & $\begin{array}{l}\text { Not Assigned } \\
\text { Opinion }\end{array}$ & Difference & Probability \\
\hline Ideological Distance & 2.11 & 2.00 & -.11 & .94 \\
\hline $\begin{array}{l}\text { Ideological Distance in } \\
\text { Politically Salient Cases }\end{array}$ & 1.66 & 1.87 & .21 & .12 \\
\hline $\begin{array}{l}\text { Ideological Distance in } \\
\text { Minimum Winning Cases }\end{array}$ & 1.83 & 1.46 & -.37 & .001 \\
\hline Assignment Cycle Equity & .16 & .34 & .18 & .000 \\
\hline Annual Equity & .42 & .43 & .01 & .71 \\
\hline $\begin{array}{l}\text { Number of Late Majority } \\
\text { Opinion Drafts }\end{array}$ & .93 & 1.05 & .12 & .01 \\
\hline $\begin{array}{l}\text { Number of Late Dissent- } \\
\text { ing Opinion Drafts }\end{array}$ & .44 & .44 & .00 & .58 \\
\hline Number of Late Votes & 1.74 & 1.92 & .18 & .01 \\
\hline
\end{tabular}

preme Court cases). Data were obtained from http://epstein.wustl.edu/research/ salience.html (last visited Mar. 21, 2006).

${ }^{86}$ Close cases are those where the conference majority or plurality had five or fewer Justices. I used Justice Blackmun's docket sheets to determine which cases did not exceed a minimum winning coalition at the conference vote.

${ }^{87}$ Since Chief Justice Rehnquist occupied one of the more extreme ideological positions on his Court, I would expect him to assign the opinion to a Justice more distant from himself (for example, the median). 


\section{Table 4: Random Effects Model of Rehnquist's Opinion} Assignment Decisions ${ }^{88}$

\begin{tabular}{|c|c|c|}
\hline \multirow[b]{2}{*}{ Variables } & Model 1 & Model 2 \\
\hline & $\begin{array}{l}\text { Coefficient } \\
\text { (Standard Error) }\end{array}$ & $\begin{array}{l}\text { Coefficient } \\
\text { (Standard Error) }\end{array}$ \\
\hline \multirow[t]{2}{*}{ Ideological Distance } & .059 & .064 \\
\hline & $(.012)$ & $(.014)$ \\
\hline \multirow[t]{2}{*}{ Politically Salient Case } & & $.152 *$ \\
\hline & & $(.086)$ \\
\hline \multirow[t]{2}{*}{ Politically Salient Case * Ideological Distance } & & $-.064 *$ \\
\hline & & $(.035)$ \\
\hline \multirow[t]{2}{*}{ Minimum Winning Conference Coalition } & & $.158 *$ \\
\hline & & $(.077)$ \\
\hline \multirow{2}{*}{$\begin{array}{l}\text { Minimum Winning Conference Coalition* } \\
\text { Ideological Distance }\end{array}$} & & $.086 * *$ \\
\hline & & $(.033)$ \\
\hline \multirow[t]{2}{*}{ Assignment Cycle Equity } & $-.444 * * *$ & $-.443 * * *$ \\
\hline & $(.049)$ & $(.049)$ \\
\hline \multirow[t]{2}{*}{ Annual Equity } & .012 & .011 \\
\hline & $(.046)$ & $(.046)$ \\
\hline \multirow[t]{2}{*}{ Number of Late Majority Opinion Drafts } & $-.042 *$ & $-.049 * *$ \\
\hline & $(.019)$ & $(.020)$ \\
\hline \multirow[t]{2}{*}{ Number of Late Dissenting Opinion Drafts } & .007 & -.007 \\
\hline & $(.019)$ & $(.019)$ \\
\hline \multirow[t]{2}{*}{ Number of Late Votes } & -.011 & -.009 \\
\hline & $(.011)$ & $(.011)$ \\
\hline \multirow[t]{2}{*}{ Constant } & $-1.011 * * *$ & $-1.080 * * *$ \\
\hline & $(.038)$ & $(.043)$ \\
\hline Number of Observations & 5437 & 5437 \\
\hline Wald Chi Squared & $95.97 * * *$ & $137.10 * * *$ \\
\hline
\end{tabular}

There is evidence from this bivariate analysis to support Chief Justice Rehnquist's assertion that he assigned opinions to Justices current

${ }^{88}$ Please note the following:

$*=\mathrm{p} \leq .05$ (one-tailed test)

$* *=\mathrm{p} \leq .01$ (one-tailed test)

$* * *=\mathrm{p} \leq .001$ (one-tailed test) 
in their work and to maintain an equitable distribution of assignments across the chambers. First, there are statistically significant associations between the Chief's assignment decisions and a Justice's number of pending majority opinion drafts and votes that are past due, according to Rehnquist. ${ }^{89}$ There is no evidence of a statistically significant relationship between overdue dissent drafts and assignment decisions. The support for equity is more complex. There is evidence that Rehnquist was reluctant to assign opinions to Justices who had received assignments from an Associate Justice. ${ }^{90}$ This reflects the tradeoffs that Chief Justices make during a single assignment cycle. In contrast, there is no evidence to support Rehnquist's assertion that he was attentive to the number of assignments a Justice received during the Term as a whole. ${ }^{91}$

These bivariate results shift somewhat when subjected to multivariate controls. $^{92}$ As seen in Table 4, Rehnquist was apt to assign the opinion, all else held constant, to a Justice who was ideologically distant from himself. This is consistent with the findings of other studies of Rehnquist's assignment decisions. ${ }^{93}$ There are two possible explanations for this pattern. First, Rehnquist may not have used his assignment powers routinely to maximize his policy gain. Instead, he may have reserved his ideological allies for especially important cases. As seen in Table 2, Rehnquist was significantly less likely to assign the opinion to an ideologically distant Justice when the case was politically salient. Interestingly, as also seen in Table 2, the pattern of favoring his ideological opponents was accentuated in cases with a fragile conference majority.

${ }^{89}$ The number of late, pending majority opinion drafts, dissenting opinion drafts, and overdue votes were derived from the opinion logs maintained by Justice Blackmun's chambers. These logs contain information on the dates when opinion drafts were circulated, as well as when Justices sent memos joining an opinion, which is the manner in which they cast their final vote.

${ }^{90}$ I used the assignment sheets found in Justice Blackmun's papers to calculate the number of assignments each Justice received from an Associate Justice. The assignment sheet designates these cases by placing the initials of the Associate Justice assigning the opinion next to the case name.

${ }^{91}$ Using information from the assignment sheets, I determined whether a Justice needed additional assignments to reach the running mean of assignments given to the Justices at that point in the Term.

${ }^{92}$ I estimate a multivariate model using random-effects probit where there is an observation for each Justice who is eligible to receive an assignment by virtue of voting with the conference majority.

${ }^{93}$ See, e.g., Maltzman \& Wahlbeck, supra note 7, at 426 (concluding that, under certain conditions, Chief Justice Rehnquist was most likely to assign opinions to Justices ideologically distant from himself). 
A second explanation for Rehnquist's equal treatment of ideological allies and other Justices is that the Rehnquist Court was more consistently conservative than the Burger Court. The Court, during much of the Rehnquist Court era, was dominated by conservative Justices, as evidenced by the shifting ideological median. In the Terms examined here, 1986 to 1993, the median Justice was significantly more conservative than the median during the Burger Court-or even the median in the post-Blackmun Rehnquist Court. ${ }^{94}$ Thus, there was little policy gain to be realized from assigning to the ideologically closest Justices, as Rehnquist could be assured of a satisfactory opinion from a number of different Justices.

The effect of the organizational needs articulated by Chief Justice Rehnquist is not as powerful when subjected to multivariate controls. The only significant workload factor, outlined in Rehnquist's 1989 memo, ${ }^{95}$ was the number of late majority opinion drafts. It is apparent that Rehnquist did penalize Justices who had a number of delinquent majority opinion drafts (that is, more than four weeks had elapsed since the Justice received the assignment). Incidentally, the effect of these workload variables is not heightened as the Court approaches the end of its Term. In addition to this workload effect, Rehnquist pursued the norm of equitable distribution of assignments within each argument session.

\section{CONCLUSION}

As we look toward the tenure of Chief Justice John G. Roberts, Jr., we can extrapolate lessons for the use of opinion assignment in guiding the Court. First, the Chief Justice can use opinion assignment to advance his policy goals. By assigning opinions to his ideological allies, the Chief Justice may realize policy gain in cases where he stands with the majority or may minimize his policy loss when the majority takes a position contrary to his. In the foreseeable future, though, Chief Justice Roberts will enjoy leading a Court where the median is a relatively conservative voice. This will enable him to distribute opin-

${ }^{94}$ Using Andrew Martin and Kevin Quinn's measure of the Court median, a difference in means test reveals that the median grows significantly more conservative from the 1986 Term to the 1993 Term. See Andrew D. Martin \& Kevin M. Quinn, Dynamic Ideal Point Estimation via Markov Chain Monte Carlo for the U.S. Supreme Court, 19531999, 10 POL. ANALYSIS 134, 134-51 (2002) (discussing the methods and datasets used to achieve these results). Martin and Quinn's data on Court ideology are available at http://adm.wustl.edu/supct.php (last visited Mar. 21, 2006).

${ }^{95}$ Rehnquist memorandum, supra note 27. 
ion assignments across many Justices without any discernable policy loss.

Nevertheless, the Chief will find himself, like Chief Justice Rehnquist, constrained by the strategic context of each case, as well as by the expectations of his colleagues. He may reserve his allies for assignments to particularly salient cases, while minimizing his policy loss in cases with close conference votes by assigning those opinions to Justices at the center of the Court's ideological spectrum. At the same time that he strives to balance these ideological considerations, Chief Justice Roberts may be attentive to the effect of opinion assignment on the operation of the Court as an organization. Specifically, the Chief Justice may, like his predecessor, equalize assignments throughout the year by giving each Justice roughly the same number of assignments each cycle. He may also use future assignments as an incentive to complete majority opinions previously assigned.

Regardless of how Chief Justice Roberts seeks to balance these competing demands, he will come to appreciate the potential and pitfalls of opinion assignment for advancing his vision of good legal policy. Depending on how he chooses to deploy assignments among his colleagues, he may also come to see the wisdom of Justice Douglas's warning that assignment tactics can lead to "a frayed and bitter Court full of needless strains and quarrels." ${ }^{96}$ In an office without many prerogatives of power, the ability to assign the task of writing opinions gives the Chief Justice the capacity to shape the Court.

${ }^{96}$ Douglas letter, supra note 6. 